\title{
PILONIDAL SINUS DISEASE: A STUDY OF THIRTY SIX CASES
}

\section{Sanjay Datey ${ }^{1}$, Rishikant Vashistha ${ }^{2}$, Apoorva Gupta ${ }^{3}$, Mohan Gadodia ${ }^{4}$, Ashwin Lazarus ${ }^{5}$, Praveen Verma ${ }^{6}$}

${ }_{1}^{1}$ Professor, Department of General Surgery, Sri Aurobindo Medical College and Post Graduate Institute, Indore. ${ }^{2}$ Assistant Professor, Department of General Surgery, Sri Aurobindo Medical College and Post Graduate Institute, Indore. ${ }^{3} 3^{\text {rd }}$ Year Surgery Resident, Department of General Surgery, Sri Aurobindo Medical College and Post Graduate Institute, Indore. ${ }^{4} 2$ nd Year Surgery Resident, Department of General Surgery, Sri Aurobindo Medical College and Post Graduate Institute, Indore. 52nd Year Surgery Resident, Department of General Surgery, Sri Aurobindo Medical College and Post Graduate Institute, Indore. ${ }^{6} 1^{\text {st }}$ Year Surgery Resident, Department of General Surgery, Sri Aurobindo Medical College and Post Graduate Institute, Indore.

\section{ABSTRACT}

Pilonidal disease is a common acquired surgical problem, which becomes the cause of marked discomfort and absentism amongst young men. It occurs in the cleavage of intergluteal cleft and is infamous for the recurrences following surgery and the associated prolonged wound care. Pilonidal sinus disease usually presents with an acute abscess, which later becomes a sinus with recurrent similar abscesses. Pilonidal sinus disease is of acquired origin and has multifactorial etiology. Many options are available in the management inclusive of conservative methods and operative procedures. Pilonidal sinus disease has remarkable recurrence rates after all the described surgical procedures. We studied cases of pilonidal sinus disease for their demographic pattern, clinical presentation and the applied surgical procedure. Recurrent pilonidal sinuses were evaluated for the possible cause of failure after previous surgical procedure. We present the article with thorough review of recent literature on pilonidal sinus disease.

\section{KEYWORDS}

Pilonidal Sinus, Intergluteal Cleft, Limberg Flap.

HOW TO CITE THIS ARTICLE: Sanjay Datey, Rishikant Vashistha, Apoorva Gupta, Mohan Gadodia, Ashwin Lazarus, Praveen Verma. "Pilonidal Sinus Disease: A Study of Thirty Six Cases. Journal of Evolution of Medical and Dental Sciences 2015; Vol. 4, Issue 97, December 03; Page: 16254-16257, DOI: 10.14260/jemds/2015/2395

\section{INTRODUCTION}

Pilonidal sinus disease is mainly a problem of young males, which can affect them from puberty to middle age. It leads to a sinus with recurrent abscesses in subcutaneous tissue of the intergluteal (Natal) cleft. The condition becomes a cause of discomfort and absentism from work for the sufferer.

Acute abscesses need to be drained followed by prolonged dressings. Meticulous hygiene with depilation of the area may dampen the severity of the disease. But more than half of these individuals ultimately go for a surgical procedure. Many surgical procedures are described for pilonidal sinus and all of them have significant number of failures in the form of a recurrent pilonidal sinus. All the described surgical procedures are designed to achieve early healing without any recurrence, but the results are contrary.

Prolonged recovery in the postoperative period is common because of wound disruptions and secondary healing, as the area is studded by notorious infective organisms. Flap procedures have better results, but as a plastic surgical expertise is needed they are usually reserved for recurrent and complex pilonidal sinuses. This article is an observational study of patients of pilonidal sinus disease for their demographic pattern, mode of clinical presentations, various surgical procedures in their management and the outcomes. Detailed review of available literature of the problem of pilonidal sinus disease is also done.

\section{REVIEW OF LITERATURE}

The term "Pilonidal" in Pilonidal Sinus Disease come from Latin ("Pillus" is Hair and "Nidus" is Nest).

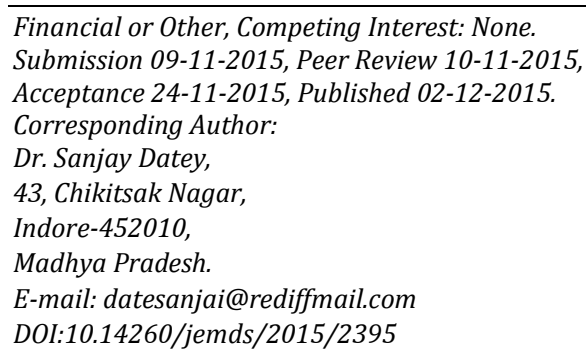

This condition was first described by Anderson in 1847 and the term was first used by Hodges in 1880.(1) Pilonidal sinus disease is rarely seen before puberty and after the age of forty years. It is common in males. Pilonidal sinus disease occurs in the subcutaneous tissue and skin of intergluteal (Natal) cleft and becomes a cause of marked discomfort and embarrassment. The disease has definite correlation with hormonal changes, which lead to increased activity of pilosebaceous glands in the area and hirsute nature of the individual.(2)

Pilonidal sinus disease was commonly seen in Jeep drivers of the army in Second World War, probably due to long hours of sitting, sweating and driving on bumpy roads and thus also called as the "Jeep Disease." A similar condition is seen in the interdigital clefts of barbers in which the customer's hair are the culprits of a chronic sinus. The etiology of pilonidal sinus disease is still obscure, although it has definite relationship with hirsute nature of the individual.

Majority of the opinion is suggestive of acquired origin and is associated with multiple factors like changes in levels of male hormones, more hair, friction due to physical activity, deep natal cleft and infections.(3,4) Sitting posture in obese subjects leads to a negative pressure between the intergluteal cleft, which sucks the fallen hair from the skin of back and draws them into a pit. Sweating, poor hygiene and infection leads to an abscess which becomes deeper in the subcutaneous tissue and forms multiple tracks. Bursting on its own or deliberate drainage of an abscess leads to chronic sinus.

Histologically studied postoperative specimens show mainly keratin, debris and hair in addition to features of chronic inflammation. Surprisingly, only half of the cases show presence of hair.(5) Excised specimens show sinus tracks, which are lined by squamous epithelium. This further proves the acquired origin of pilonidal sinus as congenital sinuses of this region are lined by cuboidal epithelium. Squamous epithelial lining can very rarely lead to malignancy. Available medical literature has at least 50 cases of squamous cell carcinoma in pilonidal sinus.(6) 
Early detection of malignancy will be rewarding as aggressive local excision followed by multimodality treatment is mandatory. (7)

Pilonidal sinus may remain asymptomatic for a considerable period. When becomes symptomatic, it usually presents as a chronic discharging sinus with previous history of an acute abscess. Acute pilonidal abscess, chronic pilonidal abscess/single discharging sinus and recurrent/complex pilonidal sinus disease with multiple openings are various ways of presentations.(8) Pilonidal sinus disease needs prompt treatment being a septic focus in body, cause of discomfort and becomes an embarrassment and reason for absentism from work for an individual. Conservative medical and surgical options are available. After the drainage of an acute pilonidal abscess, conservative measures can be tried. Conservative approach comprises of maintenance of good local hygiene and depilation of the area.

More than half of the patients $(60 \%)$ are benefited for a long period. Once a patient starts getting repeated abscesses and discharging sinuses, surgery is the only option. According to a study, about $85 \%$ patients require surgery ultimately. ${ }^{(9)}$ Many conservative methods are used and are more acceptable to patients in spite of knowing about the possibility of a recurrence. Injections of Phenol or Fibrin glue after debridements of the track are widely used methods. $(10,11)$ We have many surgical procedures from wide excision with or without closure to complex flaps to close the defect by excision. The basic aim of these surgical procedures is to expediate healing and provide a flattened surface in place of the intergluteal cleft.

Patient should return to his normal activities and work at the earliest and should never get recurrence of the pilonidal sinus. Following surgical procedures are described for pilonidal sinus disease.

Excision with laying open of the track.

Excision with primary closure.

Incision, drainage and removal of track.

Bascom Procedure.

Asymmetrical incisions and closure, e.g. Karydakis.

Flap procedures like rhomboid or limberg flap, V-Y plasty, myocutaneous flap, simple wide excision up to presacral fascia without closure of the wound is done. Wound is allowed to heal by secondary intention. Although the method has very low recurrence rates, the difficulties faced by the patient in the form of cumbersome dressings and prolonged healing time (six to eight weeks) may not be acceptable to all. Excision with primary closure is another popular method of treatment of pilonidal sinus. Primary closure in an infected area always carries a risk of wound infection and disruption, sometimes taking more time to heal than simple excision without closure. Incidence of failed primary healing is approximately $16 \%$.

This is attributed to the fact that primary closure is rarely tension free and wound is considered contaminated in spite of wide excision and debridement. Recurrence rates after primary closure may be as high as $38 \% .{ }^{9}$ Flap procedures are suitable for complex or recurrent pilonidal disease, but they require expertise. Flap procedures and excisions by assymetrical incisions take care of correction of the anatomically deep intergluteal cleft, which is the major factor in preventing recurrence. So far large controlled trials have not been conducted to compare and decide about the appropriate method of treatment, probably because of paucity of cases of pilonidal sinus disease.

Different categories of the disease call for different types of procedures. Acute abscess has to be evacuated and wound should heal by secondary intention.

Chronic pilonidal sinus disease needs wide excision, which can be done with or without closure, whereas recurrent pilonidal sinuses need wide excision with flap cover to achieve primary healing.

\section{METHODOLOGY}

This retrospective observational study was carried out in the Department of General Surgery at Sri Aurobindo Medical College and Post Graduate Institute from $1^{\text {st }}$ November 2010 to $31^{\text {st }}$ October 2015. All the patients who were admitted with pilonidal sinus disease were included in the study. The patients who left the hospital without completing the treatment were excluded. The relevent case files were retreived from the Medical Record Depatment. All the data was entered on the proforma for this study. The data was tabulated and analyzed by the descriptive statistical method of averages. Results of the study were compared with available studies in the literature. At no stage, the identity of individual patient was disclosed.

\section{OBSERVATIONS}

This retrospective study had 36 patients of pilonidal sinus disease. All the observations were analyzed and the data revealed following results:

\begin{tabular}{|c|c|c|}
\hline Sex & $\begin{array}{c}\text { Number of } \\
\text { Patients }\end{array}$ & Percentage \\
\hline Male & 31 & $86.1 \%$ \\
\hline Female & 05 & $13.9 \%$ \\
\hline \multicolumn{3}{|c|}{ Table 1: Sex Distribution of } \\
\multicolumn{3}{|c|}{ Pilonidal Sinus Disease (n36) } \\
\hline
\end{tabular}

\begin{tabular}{|c|c|c|}
\hline Age Group & $\begin{array}{c}\text { Number of } \\
\text { Patients }\end{array}$ & Percentage \\
\hline Before Puberty (15years) & nil & $0 \%$ \\
\hline 15 to 25 years & 17 & $47.2 \%$ \\
\hline 26 to 35 years & 10 & $27.7 \%$ \\
\hline 36 to 45 years & 07 & $19.4 \%$ \\
\hline 46 to 55 years & 01 & $2.7 \%$ \\
\hline Above 55 years & 01 & $2.7 \%$ \\
\hline \multicolumn{2}{|c|}{ Table 2: Age wise Distribution } \\
Pilonidal Sinus Disease (n36) \\
\hline
\end{tabular}

\begin{tabular}{|c|c|c|}
\hline Comorbidity & $\begin{array}{l}\text { Number of } \\
\text { Patients }\end{array}$ & Percentage \\
\hline Hypertension & 02 & $5.5 \%$ \\
\hline Diabetes Mellitus & 01 & $2.7 \%$ \\
\hline $\begin{array}{l}\text { Ischemic Heart } \\
\text { Disease }\end{array}$ & 01 & $2.7 \%$ \\
\hline Obesity (BMI >30) & 03 & $8.3 \%$ \\
\hline Any other & nil & $0 \%$ \\
\hline \multicolumn{3}{|c|}{$\begin{array}{c}\text { Table 3: Comorbidities in the Patients } \\
\text { of Pilonidal Sinus Disease (n36) }\end{array}$} \\
\hline
\end{tabular}

\begin{tabular}{|c|c|c|}
\hline $\begin{array}{c}\text { Family History of } \\
\text { Pilonidal } \\
\text { Sinus Disease } \\
\end{array}$ & $\begin{array}{l}\text { Number } \\
\text { of } \\
\text { Patients } \\
\end{array}$ & Percentage \\
\hline Present & 06 & $16.6 \%$ \\
\hline Absent & 30 & $83.4 \%$ \\
\hline
\end{tabular}

\begin{tabular}{|c|c|c|}
\hline Mode of Presentation & $\begin{array}{c}\text { Number of } \\
\text { Patients }\end{array}$ & Percentage \\
\hline Acute abscess & 09 & $25 \%$ \\
\hline $\begin{array}{c}\text { Chronic sinus with } \\
\text { discharge }\end{array}$ & 20 & $55.5 \%$ \\
\hline Recurrent pilonidal sinus & 07 & $19.5 \%$ \\
\hline \multicolumn{2}{|c|}{ Table 5: Mode of Presentation (n36) } \\
\hline
\end{tabular}




\begin{tabular}{|c|c|c|}
\hline Investigation & $\begin{array}{c}\text { Number of } \\
\text { Patients }\end{array}$ & Percentage \\
\hline Sinogram & 9 & $25 \%$ \\
\hline Ultrasonography & 9 & $25 \%$ \\
\hline Magnetic resonance imaging & 3 & $8.3 \%$ \\
\hline CT singoram & 1 & $8.3 \%$ \\
\hline \multicolumn{3}{|c|}{$\begin{array}{c}\text { Table 6: Investigations done if any in Patients } \\
\text { of Pilonidal Sinus Disease (n36) }\end{array}$} \\
\hline
\end{tabular}

\begin{tabular}{|c|c|c|}
\hline Treatment & $\begin{array}{c}\text { Number } \\
\text { of } \\
\text { Patients }\end{array}$ & Percentage \\
\hline Conservative & 2 & $5.5 \%$ \\
\hline $\begin{array}{c}\text { Only incision and drainage of } \\
\text { abscess with followup }\end{array}$ & 7 & $19.5 \%$ \\
\hline $\begin{array}{c}\text { Surgical procedure (Wide } \\
\text { excision with or without closure } \\
\text { or flap.) }\end{array}$ & 27 & $75 \%$ \\
\hline \multicolumn{2}{|c|}{$\begin{array}{l}\text { Table 7: Treatment Given in Patients } \\
\text { of Pilonidal Sinus Disease (n36) }\end{array}$} \\
\hline
\end{tabular}

\begin{tabular}{|c|c|c|}
\hline Surgical Procedure & $\begin{array}{c}\text { Number } \\
\text { of } \\
\text { Patients }\end{array}$ & Percentage \\
\hline $\begin{array}{c}\text { Incision/drainage of an acute } \\
\text { abscess }\end{array}$ & 5 & $13.8 \%$ \\
\hline Wide excision without closure & 5 & $13.8 \%$ \\
\hline Excision with closure & 21 & $58.5 \%$ \\
\hline Limberg Flap & 3 & $8.4 \%$ \\
\hline Conservative treatment & 2 & $5.5 \%$ \\
\hline \multicolumn{3}{|c|}{$\begin{array}{c}\text { Table 8: Surgical Procedures in } \\
\text { Various Patients (Total number }=36 \text { ) }\end{array}$} \\
\hline
\end{tabular}

\begin{tabular}{|c|c|c|}
\hline Surgical Procedure & $\begin{array}{c}\text { Number of } \\
\text { Patients }\end{array}$ & $\begin{array}{c}\text { Average } \\
\text { Stay }\end{array}$ \\
\hline Incision and Drainage & 7 & 2.13 days \\
\hline $\begin{array}{c}\text { Wide excision without } \\
\text { closure } \\
\text { (Healing by 2nd } \\
\text { intention) }\end{array}$ & 5 & 5.27 days \\
\hline $\begin{array}{c}\text { Wide excision with } \\
\text { closure }\end{array}$ & 21 & 4.56 days \\
\hline Limberg Flap & 3 & 6.45 days \\
\hline $\begin{array}{c}\text { Table 9: Average Postoperative } \\
\text { Stay after Surgical Procedures }\end{array}$ \\
\hline \multicolumn{2}{|c}{} \\
\hline
\end{tabular}

\section{DISCUSSION}

Clinical presentation in the 36 patients of our study was compared with that of other studies. Males were commonly affected in our study and comprised of $86.1 \%$, similar to the incidence in a study done by Sondenaa et al.(2) in which pilonidal sinus disease was found to be 2.2 times more common in males than in females. Age group (15-25 years) was found to be the commonest sufferer (47.4\%). Sondenaa et al. described that average age as 21 years for males and 19 for females.(2)

Males predominantly suffer because of hormonal changes leading to increased activity of pilosebaceous glands and females due to anatomically deep intergluteal cleft. History of pilonidal sinus disease in the family seems to be an important factor in all the studies in the literature. ${ }^{(2,12)}$ In our study, positive family history of pilonidal sinus disease was noted in 6 out of 36 cases in comparison to 18/88 in a study by Omer et al. and 38\% in the study by Sondenaa et al.(2,12)
Anatomical configuration of an individual like depth of intergluteal cleft and number of hair is genetically determined factors and thus family history plays an important role. Sondenaa et al. had a significant number of obese $(37 \%)$ individuals in their study of 322 patients. Our study shows involvement in three obese (BMI more than 30) individuals. Obese persons are at a higher risk because of a deeper intergluteal cleft and greater friction during the activity. Maintenance of proper hygiene is sometimes difficult due to inaccessibility of the area due to obesity.

Omer et al. reported that 34 out of 88 patients in their series were obese with weights more than 90kgs.(12) Management depends on the mode of presentation of the patient. Acute abscess has to be managed by drainage as wider resections may spread the infection through the tissue planes. Conservative treatment of improving the local hygiene and depilation may keep the patient asymptomatic for long periods. Chronic sinus with recurrent infections causing discomfort to the patient with increasing absentism from work has to be treated by surgical procedure. Surgical procedure should be able to cure the condition. So far all the methods described for this condition have significant number of recurrences.

Primary recurrence which becomes evident within a few days of surgical procedure are because of failure to excise the track completely. Secondary recurrence is due to anatomically deep intergluteal cleft and hairy back with poor hygiene. Surgical procedure will have good result when the whole track is excised and deep intergluteal cleft is flattened by bringing a flap of surrounding tissue. Limberg flap or rhomboid flap has the best results and is the treatment of choice in recurrent or complex or for that matter all the pilonidal sinuses. (9) We had seven patients of recurrence after a surgical procedure in which drainages of abscesses are not included. A large controlled trial of different methods of treatment is needed to solve this issue.

\section{CONCLUSION}

Pilonidal sinus disease is relatively uncommon, but has serious impact on the sufferer and form severe discomfort and absence from work. Recurrent pilonidal sinus after a failed surgical procedure is another significant issue. A large multicenter trial of all the methods is required to reach a consensus about the treatment. Wide excision of affected tissue, removal of the sinus track completely and flattening of the intergluteal cleft by flap method is recommended treatment for today.

\section{REFERENCES}

1. Hodges RM. Pilonidal Sinus. Boston Med Surg 1880;103:485-486.

2. Sondenaa K, NesvikI, Anderson E, Natas O, Soreide JA. Patient Characteristics and Symptoms in Chronic Pilonidal Sinus Diseae. Int J Colorectal Dis 1995;10(1):3942.

3. Dwight RW, Maloy JK. PilonidalSinus: experience with 449 cases. N Engl J Med 1953;249:926-30.

4. Akinci OF, Kurt M, Terzi A, Atak I, Subasi IE, Akbilgic O. Natal cleft deeper in patients with Pilonidal Sinus: Implications for choice of surgical procedure. Dis Colon Rectum 2009 May;52(5):1000-2.

5. Bascom JU. Pilonidal Disease: Correcting over treatment and undertreatment. Contemporary Surg 1981;18:13-28.

6. Lineaweaver WC, Brunson MD, Smith JF, Franzin DA, Rumley TO. Squamous cell carcinoma arising in pilonidal sinus. J Surg Onco 1984;27(4):39-42.

7. Kulaylat MN, Gong M, Doerr RJ. Multimodality treatment of squamous cell carcinoma complicating pilonidal disease. Am Surg 1996 Nov; 62(11):922-9. 
8. Solla JA, Rothenberger DA. Chronic Pilonidal Disease. An assesment of 150 cases. Dis Col Rec 1990;7(9):758-61.

9. Amit Khanna, John L, Rombeau. Pilonidal disease. Clin Colon Rectal Surg 2011 Mar;24(1):46-53.

10. Stansby G, Greatorex R. Phenol treatment of pilonidal sinuses of the natal cleft. Br J Surg 1989 Jul;76(7):729-30.
11. Lund JN, Leveson SH. Fibrin glue in the treatment of pilonidal sinus: results of a pilot study. Dis colon Rectum 2005(May);48(5):1094-96.

12. Omer Faruk Akinci, Mikdat Bozer, Ali Uzunkoy, Sukru Aydin Duzgun, Ali Coskun. Incidence and Aetiological factors in Pilonidal Sinus among Turkish Soldiers. The European Journal of Surgery1999;165(4):339-342. 